\title{
Early Childhood Sex Education in Coastal Areas
}

\author{
$1^{\text {st }}$ Pahlita Ratri Ramadhani \\ Graduate School of Yogyakarta State \\ University \\ Yogyakarta, Indonesia \\ pahlitaratri@gmail.com
}

\author{
$2^{\text {nd }}$ Amir Syamsyudin \\ Graduate School of Yogyakarta State \\ University \\ Yogyakarta, Indonesia
}

\begin{abstract}
Today, child sexual abuse was increasingly prevalent. In fact, these actions of sexual abuse are carried out by those closest people, including family. The most of people community considers that sexual education is a taboo thing to be taught to young children. The effect of the lack of public awareness about the importance of sexual education in early years can cause of sexual deviations behavior. This study aimed to determine the implementation of sex education in early childhood in coastal areas. The study uses qualitative research methods with a phenomenological approach. Research subjects are parents in coastal areas. The results showed that early childhood children in the coastal areas did not get sexual education in early years, parents considered that children were not yet time to be taught matters related to reproductive health, and the assumption believe that sex education would be taught by teachers in school.
\end{abstract}

Keywords-Early Childhood, Sex Education, Coastal Areas

\section{INTRODUCTION}

Sexuality is the most important aspect of human personality In a broad sense, sexuality refers to all aspects consisting of men or women and the concept has biological, psychological, behavioral, clinical, cultural, social, moral, religious and educational dimensions. Sex education is best described as the influence exerted on the development of human sexuality starting from the influence of family in the first few years of life to schools and other social factors [1]. Sex education refers to aspects of sexual health related to achieving results that are generally seen as positive (respecting oneself and others, non-exploitative sexual satisfaction, respecting human relationships, and being planned parents) and avoiding negative outcomes (such as unwanted pregnancy, and STI / HIV) [2].

Introducing early sex education is essential so children can protect themselves from sexual crimes [3]. The impact of violence or sexual abuse on early childhood is extremely influential on children psychological development. The short-term effects includes physical pain, guilt, fear, anxiety, shame, anger, and helplessness while the long term effects is a certain psychological symptom felt by the victim as a trauma that leads to a feeling of distrust. Early childhood sex education is an effort to provide information or knowledge to children about identifying body parts, function of body parts, the importance of looking after body parts, as well as differences in men and women [4].

Sexual development of children is still a taboo subject and has generated controversy among people [5]. Most parents feel ashamed to talk openly about sex to children [6]. Some parents often refuse to answer children's questions about sex. Thus, children avoid talking about sexual problems for fear that showing a curiosity about sex will arouse suspicion about their behavior [7]. Parents perceive that sex education only teaches about reproductive organs and that it is inappropriate to use terms such as penis or vagina when talking to children. They still think that sex education is only related to biological aspects [8].

Parents assume that teacher is the one who is responsible for providing sex education to children. They tend to be passive in providing sex education for children [9]. Several factors influence this phenomenon such as environmental factors, level of education, experience, religious beliefs, and social and cultural perspectives. Parents with poor socio-economic conditions and low education participate less in children's education especially in early childhood sex education [10].

The Witness and Victim Protection Agency (LPSK) noted an increase of requests for protection of sexual violence cases against children. The number even exceeds other criminal acts. LPSK noted that there was an increase of 25 cases of sexual violence against children that occurred since 2016. The number rose to 81 cases in 2017 and reached the peak of 206 cases in 2018 . The number of cases continues to grow every year. Up to June 2019, there were 78 requests for protection and legal assistance against crimes of sexual violence towards children. Cases of sexual violence against children is dominated by closest people $(80.23 \%)$ while $19.77 \%$ is committed by strangers [11].

The emergence of behavior to carry out simple explorations and discoveries that go beyond "head and shoulders, knees and feet" occur during childhood. Starting from infancy, children begin to experience natural discoveries from all body parts including genitals. A number of studies have attempted to study the typical and general sexual behavior observed in childhood compared to unusual and disturbing sexual behavior. Common sexual behaviors during childhood include: wanting close body 
contact, touching genitals, wanting to see other people genitals, showing their own genitals to others, and trying to touch a woman's breasts. As a child's curiosity and exploration develops, children begin to build knowledge and sexual attitudes which are based on support (or lack of support) and the response of parents and or caregivers [12].

Based on the background above, the researcher aim to describe the experience of parents in providing sex education to young children in coastal areas. This research is expected to be able to broaden the insight of readers, especially parents, about the importance of early sex education for their children.

\section{EARLY CHILDHOOD SEXUAL} DEVELOPMENT STAGE

Early childhood period, especially between ages $0-6$, is a critical period where children learn at the fastest pace. In this period when children personality is formed, they need guidance from sources who are knowledgeable in the developmental field such as children sexual development. As with many other subjects, placing the importance of sexual education in this period has many benefits in terms of children development [13].

Almost all young children touch and explore their genitals. They do this by using hands, objects (e.g, toys, stuffed animals, blankets), or by rocking their body against stuffed animals or rubbing furniture. Preschoolers can experiment by sticking their fingers or other objects in their vagina or rectum; this usually causes pain or discomfort, and they stop doing it. Boys touch their genitals more often than girls. For example, in a normative sample of children, $67 \%$ of boys aged 3 to 5 years and $55 \%$ of girls were reported by their mothers to touch their genital at home; $39 \%$ of boys and $19 \%$ of girls touched their genitals in public [14].

The stages of a child's sexual development come into several periods, namely: (1) A period of 0-2 years, during which the baby begins to learn about love and trust through touch and hug; very responsive to physical touch and receive verbal / nonverbal messages that will shape their understanding of sexuality; (2) Period of 3-4 years, during which the child's gender identity begins to develop; children begin to understand about gender (that they are male or female); exploring body parts with playmates is normal; children at this age begin to touch their genitals; the desire to know the body part of their playmates arises; (3) 5-7 years, during which children begin to build the foundation of gender identity; children explore adult roles by playing roles as if they were adults of a certain status; children tend to look for stronger relationships with samesex parents; exploring body parts at this age is also natural; children begin to understand gender differences better, but are not particularly interested in the opposite sex; they begin to understand the roles of men and women through parents or media [15].

Early childhood sexual development includes: exploring and touching private parts, rubbing private parts (with hands or against objects), showing private parts to others, trying to touch women's breast, removing clothes and wanting to get naked, trying to see other people when they are naked or undressing (like in the bathroom), asking questions about their bodies and bodily functions, talking to children their age about bodily functions such as "pooping" and "urinating", deliberately touching their private part (masturbation) sometimes in the presence of others, trying to see others when they are naked or undressed, imitating dating behavior (such as kissing, or holding hands), and talking about private parts and using "naughty" words [ [16]; [17]; [18]].

Preschoolers are very interested in the physical differences between boys and girls. When young children are given the opportunity to play, the possibility of sexual exploitation with other children can occur. The game "sex" is a very common phenomenon among this age group (for example, playing "doctor" or "mother and father," that involves showing the body parts of each other. Children make an agreement to show their body parts to each other. This game is usually played between children (cross-sex but most are same sex) with children within the same age [19].

\section{EARLY CHILDHOOD EDUCATION IN COASTAL AREAS}

Indonesia is an archipelago with a vast coastal region that stretches and surrounds this country. The 1945 Constitution in article 25A states that the Unitary State of the Republic of Indonesia is an archipelagic country characterized by archipelago with territories whose boundaries and rights are determined by Law [20]. Most residents who live in coastal areas work as fishermen and farmers. Indonesia's marine resources are very abundant yet the quality of human resources are unfortunately insufficient.

Coastal areas are geomorphological areas on both sides of the coast where interactions between parts of the sea and land occur in the form of complex ecological and resource systems consisting of biotic and abiotic components that coexist and interact with human communities and relevant socio-economic activities [21]. Generally, the level of education of coastal communities is low. As a result, they cannot utilize the sea resources to the fullest. Thus, they only rely on their livelihoods as fishermen, laborers, and farmers. The low awareness of education especially early childhood education is a problem that is often found in coastal areas [22]

Based on the results of observations, the researcher found that the condition of early childhood education institutions in coastal areas was alarming. The building consisted of offices and classroom that were separated by only a partition of wood. Furthermore, many in-door and out-door games were already broken, and there was only one class teacher. The teacher is a non-permanent teacher from a private organization whose wage is poor.

\section{METHODS}

A qualitative research approach with a phenomenological design was used to explore the experiences and perspectives of parents in providing sex education to young children in coastal areas. This study involved ten parents who had young children in coastal areas. Data were collected by approaching the community 
and field surveys to obtain a valid picture about the state of the subject's environment.

In this study, phenomenological methodology is used to understand and describe a particular phenomena in order to arrive at the essence of the experience of parents in educating their children. Creswell states that "basic phenomenology is an attempt to construct a universal essence of a particular phenomenon" [23]. The purpose of this study is to extract the profound understanding regarding the experience of the participants about the implementation of sex education in early childhood into a description of the essence of phenomenon.

\section{RESULT AND DISCUSSION}

For some people, sex education is considered as taboo. The community believes that children will get knowledge about sex education when they grow up. The researcher found that eight out of ten parents in the coastal areas have not yet realized the importance of early sex education for their children.

The community stated that there was indeed no education about early childhood sex education. There are plans to hold counseling about sex education in early childhood for kindergarten educators. However, this has not been carried out due to the parties being busy. Meanwhile, parents have not yet agreed to hold counseling on early childhood sex education.

WS, AK, LS, TR, and AM, five out of ten parents, stated that talking about sex to children is inappropriate, especially if the child is still young.

"Sex is a husband and wife intercourse that should not be discussed with children. If children are given the knowledge it will arouse their curiosity that may lead to sexual disorders. "(WS, $A K, L S$, $T R$, and $A M$ )

Meanwhile, SY, BM, and RR stated that sex education provided to children was limited to wearing clothes that covered private body parts in accordance with Islamic teachings. Close relatives such as a good brother, uncle, aunt, grandmother, and grandfather, are allowed to clean child's body parts or bathing child and cleaning child's genitals during pooping and urinating.

"Sex education is limited to teaching children that it is compulsory for moslem to cover their private parts. Children can follow anyone who'd like to take care of them as long as it is family. Close relatives who care for children are not limited to touch the child's body parts. For example, a child who wet or defecate themselves can be cared by a person who is with the child and caring for him/her." (SY, BM, and RR)

$\mathrm{SA}$ and VN are two parents who began to realize the importance of sex education from an early age. Both revealed that children have been introduced to important parts of their bodies that should not be touched by others. Children were taught to practice using toilet and to close the door when using toilet.

"I have taught the children about the importance of taking care of body so they are aware that they cannot let other people to touch them. Since they were little, I also taught them to use toilet by closing the door then flushing the toilet with water until clean after using it. I have also explained to my extended family to not bathe or clean my child's genitals. "(SA and VN)

The results of the research above shows that early childhood sex education is still considered as inappropriate thing to be taught to children. Eight out of ten parents felt ashamed to talk about sex with children. Parents were afraid if children become curious and that it leads to sexual disorders later in life.

Parents who feel ashamed to openly talk about sex to their children resulted in children having little information about sex [6]. Meanwhile, sex education is important for developing skills that enable children to look after themselves. Limited sexual knowledge increases children's curiosity. However, parents often do not provide detailed explanations when children ask questions related to sex. As a result of parental attitudes that are less open, children eventually begin to avoid talking about sexual problems for fear that parents will become suspicious of them [7].

Parents' limited knowledge of sexual education can also lead to an increase in sexual crime in early childhood. The mistake of parents is relying on educational institutions for providing early sex education. Basically, sex education depends on the support of parents at home, both to explain the concepts and to help children apply their new knowledge in everyday life. Parents should act as teachers who explain things related to sex to children in order to prevent sexual crimes [24].

Training parents to teach children the right way to introduce genitals and other reproductive organs can help increase the empowerment of young people to stop child sexual abuse. In addition, educating children can improve family communication about child sexual abuse [25].

Sexual education that is considered taboo in the community makes parents in the coastal areas feel embarrassed and reluctant to talk about sex with their children. In addition, early sex education is considered as unimportant and violates the norms of decency in the culture of society [2]. Understanding sex education that develops in society is limited to the knowledge of genitals and conjugal relationships [8].

The majority of people in the coastal areas are Moslem. Most parents assume that it is enough to teach children to wear clothes that cover their genitals. It is important for Moslem parents to be proactive and open in discussing sexual problems that are appropriate for children. Islam has provided information and guidelines on sexual matters that can be applied by parents according to the needs of their children [26].

The need for parental involvement in providing sex education can reduce the risk of negative sexual behavior among children. This is because sex education provides an understanding of the limits of what may and may not be done so that children can avoid inappropriate acts that should not be done because of ignorance [4].

\section{CONCLUSION}

Based on the research results above, it can be stated that Early childhood sex education is still considered 
inappropriate to teach children. Eight in ten parents feel embarrassed talking about sex with their children. Parents are afraid that their children will become curious and this will lead to sexual abuse in the future. Meanwhile, sex education is important for developing skills that allow children to take care of themselves. Limited sexual knowledge increases children's curiosity.

Limited parental knowledge about sexual education can also lead to an increase in sexual crimes in early childhood. Other than that, Training parents to teach children how to properly introduce genitals and other reproductive organs can help increase empowerment of adolescents to stop child sexual abuse. Sex education, which is considered taboo in society, makes parents in coastal areas feel ashamed and reluctant to talk about sex with their children. The need for parental involvement in providing sex education can reduce the risk of negative sexual behavior in children.

\section{REFERENCES}

[1] A. Kakavoulis, "Early Childhood Sexual Development and Sex Education: A Survey of Attitudes of Nursery School Teachers," European Early Childhood Education Research Journal, vol. 6, no. 2, pp. 55-70, 1998.

[2] T. Odek, "Cultural Callenges and Sex Education in Mageta Islands, Kenya," Afrika Regional Sexuality Resource, pp. 1-26, 2006.

[3] B. Astuti, Sugiyatno and S. Aminah, "The Development of Early Childhood Sex Education Materials for Early Childhood Education (ECE) Teachers," Jurnal Pendidikan dan Pemberdayaan Masyarakat, vol. 4, no. 2, pp. 113-120, 2017.

[4] Alucyana, "Pendekatan Metode Bermain Peran untuk Pendidikan Seks Anak Usia Dini," Jurnal Pendidikan Islam Anak Usia Dini, vol. 1, no. 1, pp. 1-16, 2018.

[5] C. Davies and K. Robinson, ", K. (2010). Hatching Babies and Stork Deliveries: risk and regulation in the construction of children's sexual knowledge," Contemporary Issues in Early Childhood, vol. 11, no. 3, pp. 249-262, 2010.

[6] L. Lukolo and A. Dyk, "Parents' Participation in the Sexuality Education of Their Children in Rural Namibia: A Situational Analysis," Global Journal of Health Science, vol. 7, no. 1, pp. 35$45,2015$.

[7] E. Asekun-Olarinmoye, M. Dairo and A. Adeomi, "Parental attitudes and practice of sex education of children in Nigeria," International journal of child health and human development, vol. 4, no. 3, pp. 301-307, 2011

[8] S. M. Ballard and K. H. Gross , "Exploring Parental Perspectives on Parent-Child Sexual Communication," American Journal of Sexuality Education , p. 4:40-57, 2009.

[9] Y. Widyawati, W. Pandia and E. Indriati, "Sexual Education Knowledge for Early Childhood," Advances in Social Science, Education and Humanities Research (ASSEHR), vol. 58, pp. 446450, 2017.

[10] C. Kelleher, D. Boduszek, A. Bourke, O. McBride and K. Morgan, "Parental involvement in sexuality education: advancing understanding through an analysis of findings from the 2010 Irish
Contraception and Crisis Pregnancy Study," Sex Education, vol. 13, no. 4 , p. 459-469, 2013.

[11] M. Alfons, "LPSK: Kasus Kekerasan Seksual pada Anak Meningkat Tiap Tahun," Detik News, Indonesia, 2019.

[12] S. Davies, D. Glaser and R. Kossoff, "(). Children's sexual play and behavior in pre- school settings: Staff's perceptions, reports, and responses," Child Abuse \& Neglect, vol. 24, no. 10, pp. 1329-1343, 2000.

[13] M. Kurtuncu, L. U. Akhan, I. M. Tanir and Yildiz, H., "\& (). The Sexual Development and Education of Preschool Children: Knowledge and Opinions from Doctors and Nurses," Sex Disabil, vol. 33, p. 207-221, 2015.

[14] Larsson, I, Svedin, C.-G. and Friedrich, W., "Differences and similarities in sexualbehaviour among pre-schoolers inSweden and USA," Nordic Journal of Psychiatry, vol. 54, p. 251-257, 2000.

[15] Erhamwilda, A. B. Suhardini and N. Afrianti, "Analysis of Early Childhood Teacher Perceptions of Sex Education in an Islamic Perspective," MIMBAR, vol. 33, pp. 81-89, 2017.

[16] N. G. T. Force, "Guidelines for comprehensive sexuality education: Kindergarten-12th grade, 3rd edition," New York, NY: Sexuality Information and Education Council of the United States, 2004. [Online]. Available: http://www.siecus.org/ data/global/images/guidelines.pdf. [Accessed 23 January 2020].

[17] N. Elkovitch, R. D. Latzman, D. J. Hansen and M. F. Flood, "Understanding Child Sexual Behavior Problems: A Developmental Psychopathology Framework," Clinical Psychology Review, vol. 29, p. 586-598, 2009.

[18] J. Silovsky and L. Niec, "Characteristics of Young Children WithSexual Behavior Problems: A Pilot Study," Child Maltreatment, vol. 7, p. 187-197, 2002.

[19] N. Sandnabba, P. Santtila, M. Wannäs and K. Krook, "Age and gender specific sexual behaviors in children," Child Abuse \& Neglect, vol. 27, p. 579-605, 2003.

[20] M. Indra, "URGENSI PENGELOLAAN WILAYAH PERBATASAN DALAM KAITANNYA," JURNAL SELAT, vol. 1, no. 1, pp. 13-18, 2013.

[21] M. Garriga and I. J. Losada, "Education and training for integrated coastal zone management in Europe," Ocean and Coastal Management, p. 53: 89-98, 2010.

[22] A. Kurniawan , "EDUCATION FOR MARGINALIZED COMMUNITIES AS ALTERNATIVE SOLUTION ON THE COASTAL AREAS," Cendekia , pp. Volume 14, Nomor 2: 175192, 2016.

[23] J. W. Creswell, Qualitative inquiry \& research design: Choosing among five approaches. 2nd edn., California: Sage, 2007.

[24] S. K. Wurtele and M. C. Kenny, "Partnering with Parents to Prevent Childhood Sexual Abuse," Child Abuse Review , p. Vol. 19: 130$152,2010$.

[25] P. Manyike, J. Chinawa, E. Aniwada , N. Udechukwu, C. Eke and T. Chinawa , "Impact of parental sex education on child sexual abuse among adolescents," Nigerian journal of paediatrics , p. 42 (4): $325-328,2015$.

[26] S. A. Sudan, "Educating Children on Sexual Matters Based on the Teaching of Islam: The Role of Muslim Parents," Journal of Education \& Social Policy, pp. Vol. 2, No. 5: 109-114, 2015. 